\title{
EDITORIAL
}

Special issue of Regional Studies

\section{Regional and spatial issues in the financing of small and medium size enterprises and new ventures}

\author{
Elisa Ughetto, Marc Cowling, and Neil Lee
}

\begin{abstract}
[This editorial introduces the articles addressing regional and spatial aspects relating to the demand for, and the supply of, finance for SMEs and start-ups. Reflecting the breadth of financial instruments that are potentially available to SMEs and new ventures (e.g. BA, bank credit and credit card financing), this special issue offers a combination of up-to-date studies that integrate the regional and spatial perspective into the debate on SMEs and start up financing. Overall, the papers contribute to an understanding of the mechanisms by which geography shapes access to finance for SMEs and new ventures and the implications on local economic activity.]
\end{abstract}

The lack of access to finance is one of the most important constraints on the growth of Small and Medium-Sized Enterprises (SMEs) and new ventures (Carpenter \& Petersen, 2002; Fritsch \& Storey, 2014). The pressing financial needs of SMEs and start-ups, together with the growing and everchanging opportunities for investors, have led to new forms of financial intermediation beside the traditional sources and often in combination with them (Block, Colombo, Cumming \& Vismara, 2018). Many equity and debt based financing opportunities are now available for SMEs, ranging from traditional bank loans, to publicly guaranteed loans, to venture capital (VC) and private equity financing, to business angels (BAs) and crowdfunding.

Access to these forms of financing however may be conditional on the local environment and therefore be place specific. Yet, regional and spatial issues have been relatively neglected in the literature on SME finance. This is surprising given the policy relevance of firm financing in local and regional ecosystems, especially in lagging regions (Craig, Jackson \& Thomson, 2008; Crocco, FariaSilva, Paulo-Rezende \& Rodríguez-Fuentes, 2014). Studies that explore the regional and geographical dimensions of the supply and demand for capital are rather underdeveloped and often not conclusive. A number of works in the banking literature tradition have investigated the linkage between borrower-bank proximity and credit availability/quantity, without coming to clear-cut results. While it has been documented that proximity alleviates credit constraints and favours access to finance (Agarwal \& Hauswald, 2010; Bellucci, Borisov \& Zazzaro, 2013), other studies did not find any evidence in this direction (Carling \& Lundberg, 2005). Evidence on spatial variation in the 
cost of credit is still fairly scant and little is known about how recipient regional economies are affected by changes in the traditional bank-SME relationship, in the banking system (Basel II and III) and in the financial markets (Mercieca, Schaeck, \& Wolfe, 2009; Scellato \& Ughetto, 2010).

Regional differences in the financing of SMEs and start-ups mostly derive from an uneven geographical distribution of investments, innovation and entrepreneurial opportunities (Fritsch \& Noseleit, 2013; Lee \& Brown, 2017). For example, huge differences can be envisaged in the concentration and provision of capital from banks at national, regional and local levels and in the level of development of the local financial ecosystem. The clustering of investment opportunities and specialist investors in "core regions" more than in "peripheral regions" reinforces credit constraints dynamics for SMEs operating in spatially remote regions. Much can be said of BA and VC activity, which is unequally distributed across cities, regions and nations (Mason \& Pierrakis, 2013; Tenca, Croce \& Ughetto, 2018). Likewise, new research on crowdfunding suggests that there are unique spatial dimensions which merit further investigation (Mollick, 2014). The absence of a florid financial ecosystem with a poorly developed banking system and the scarce presence of VC and BA financing (i.e. the so called 'thin markets') has implications for how local SMEs or start-ups are financed, limiting their growth possibilities (Bertoni, D’Adda \& Grilli, 2016). These issues have relevance for policy-makers concerned with improving access to funding for SMEs. Allegedly, assessing the relative strengths of alternative configurations, at regional level, of public interventions to support the development of efficient capital markets and other regional SME policy instruments is increasingly becoming a priority for policy.

Moreover, since the collapse of Lehman in 2008, we have entered a unique period in history. Many large banks have failed, many have been taken into public and quasi-public ownership, VC has diminished, and policy-makers have been extraordinarily active in capital markets. The global financial crisis, which struck most of the world's national and regional economic systems, has led to calls for a further reflection on the evolution of the financial system and of the financing instruments to sustain entrepreneurship and firms' growth (Lee, Sameen \& Cowling, 2015). However, the spatial and regional dimensions of the crisis have received thus far less attention and need further corroboration. This is somewhat surprising given that the exploration of this issue can provide significant policy suggestions to overcoming funding gaps in the different segments of the financial markets.

The collection of papers in this special issue advance academic knowledge on regional and spatial aspects relating to the demand for, and the supply of, finance for SMEs and start-ups. Reflecting the breadth of financial instruments that are potentially available to SMEs and new ventures (e.g. BA, bank credit and credit card financing), this special issue offers a combination of up-to-date studies that integrate the regional and spatial perspective into the debate on SMEs and start up financing. 
These studies are characterized by different and yet complementary units of analysis, theoretical insights and methods.

The complex interaction between the development of a local financial ecosystem, firm-level innovation propensity and BA financing is central to Grilli (2019, this issue). By analysing the Italian context, the author examines whether innovative start-ups are more likely to be funded by BAs in regions characterized by a florid financial ecosystem (in terms of availability of VC and bank financing). The author finds that the probability of getting BA financing is lower when innovative start-ups are located in weak local financial ecosystems. In these areas, angel investing does not represent a viable solution to the alleviation of regional funding gaps left by more institutionalized financial intermediaries.

In thin markets where the presence of $\mathrm{VC}$ and BA financing is limited and conventional debt and equity finance are harder to obtain, SMEs often rely on other instruments, such as credit card usage, to overcome temporary resource constraints. Brown, Liñares-Zegarra \& Wilson (2019, this issue) perform an empirical analysis on the use of credit card financing by UK SMEs from a spatial perspective. The authors provide evidence that SMEs located in peripheral geographical areas rely more on credit card financing than counterparts located in core locations, especially when they are innovative, growth- and export-oriented.

Changes in local bank presence induced by the effects of the financial crisis are explored by Hasan, Jackowicz, Kowalewski \& Kozłowski (2019, this issue). Using data from Poland from the period 2009-2014, the authors explore to what extent changes strengthening the relationship banking model shape local economic activity in the post crisis period. They find that an increase in the number of bank branches and the entry of new banks are associated with local labour market improvements and easier SME access to bank debt. However, the pace of new local firm creation has been stimulated, in the post financial crisis period, only by the acquisition of commercial banks by aggressive owners.

Overall, the papers in this issue contribute to an understanding of the mechanisms by which geography shapes access to finance for SMEs and new ventures and the implications on local economic activity. In sum, these works offer new insights into SME financing dynamics and into the evolution of the financing landscape from a regional and spatial perspective, based on different theoretical and analytical approaches. The papers also provide a valuable contribution in terms of policy implications. Although financing remains a key driver of growth for SMEs and new ventures, the traditional sources of bank and equity finance are increasingly difficult to be obtained, especially when firms are located in remote geographical areas (Mason \& Harrison, 2003; Zhao \& Jones-Evans, 2017). Therefore, regional financial policies should be designed by adopting a more systemic and hands-on policy approach, in order to better target those regions characterized by a weak financial 
ecosystem. Moreover, policy makers should better focus on local effects when taking decisions that influence the structure and health of the financial ecosystem.

\section{$\underline{\text { References }}$}

Agarwal, S., \& Hauswald, R. (2010). Distance and private information in lending. Review of Financial Studies, 23, 2757-2788.

Bellucci, A., Borisov, A., \& Zazzaro, A. (2013). Do banks price discriminate spatially? Evidence from small business lending in local credit markets. Journal of Banking \& Finance, 37, 4183-4197.

Berger, A.N., Cerqueiro, G., \& Fabiana Penas, M. (2015). Market size structure and small business lending: Are crisis times different from normal times? Review of Finance, 19, 1965-1995.

Bertoni, F., D’Adda, D., \& Grilli, L. (2016). Cherry-picking or frog-kissing? A theoretical analysis of how investors select entrepreneurial ventures in thin venture capital markets. Small Business Economics, 46(3): 391-405.

Block, J.H., Colombo, M.G., Cumming, D.J., \& Vismara, S. (2018). New players in entrepreneurial finance and why they are there. Small Business Economics, 50(2), 239-250.

Brown, R., Liñares-Zegarra, J., \& Wilson, J.O.S. (2018). Sticking it on plastic: credit card finance and small and medium-sized enterprises in the UK, Regional Studies, DOI: 10.1080/00343404.2018.1490016

Carling, K., \& Lundberg, S. (2005). Asymmetric information and distance: An empirical assessment of geographical credit rationing. Journal of Economics and Business, 57, 39-59.

Carpenter, R., \& Petersen, B. (2002). Capital market imperfections, high-tech investment and new equity financing. Economic Journal, 112, 54-72.

Craig, B.R., Jackson, W.E., \& Thomson, J.B. (2008). Credit market failure intervention: do government sponsored small business credit programs enrich poorer areas? Small Business Economics, 30(4), 345-360.

Crocco, M., Faria-Silva, F., Paulo-Rezende, L., \& Rodríguez-Fuentes, C.J. (2014). Banks and regional development: An empirical analysis on the determinants of credit availability in Brazilian regions. Regional Studies, 48(5), 883-895. 
Fritsch, M., \& Noseleit, F. (2013). Indirect employment effects of new business formation across regions: The role of local market conditions. Papers in Regional Science, 92(2), 361-382.

Fritsch, M., \& Storey, D. (2014). Entrepreneurship in a regional context: Historical Roots, recent developments and future challenges. Regional Studies, 48 (6), 939-954.

Grilli, L. (2018). There must be an angel? Local financial markets, business angels and the financing of innovative start-ups, Regional Studies, DOI: 10.1080/00343404.2018.1479524

Hasan, I., Jackowicz, K., Kowalewski, O., \& Kozłowski, L. (2019). The economic impact of changes in local bank presence. Regional Studies, DOI: 10.1080/00343404.2018.1475729

Lee, N., Sameen, H., \& Cowling, M. (2015). Access to finance for innovative SMEs since the financial crisis. Research policy, 44(2), 370-380.

Lee, N., \& Brown, R. (2017). Innovation, SMEs and the liability of distance: The demand and supply of bank funding in UK peripheral regions. Journal of Economic Geography, 17(1), 233-260.

Mason, C., \& Pierrakis, Y. (2013). Venture capital, the regions and public policy: Tthe United Kingdom since the post-2000 technology crash. Regional Studies, 47(7), 1156-1171.

Mason, C., \& Harrison, R. (2003). Closing the regional equity gap? A critique of the Department of Trade and Industry's Regional Venture Capital Funds initiative. Regional Studies, 37(8), 855-868.

Mercieca, S., Schaeck, K., \& Wolfe, S. (2009). Bank market structure, competition, and SME financing relationships in European regions. Journal of Financial Services Research, 36(2-3), 137155.

Mollick, E. (2014). The dynamics of crowdfunding: An exploratory study. Journal of Business Venturing, 29(1), 1-16.

Scellato, G., \& Ughetto, E. (2010). The Basel II reform and the provision of finance for R\&D activities in SMEs: An analysis for a sample of Italian companies. International Small Business Journal, 28(1), 65-89.

Tenca, F., Croce, A., \& Ughetto, E. (2018). Business angels research in entrepreneurial finance: A literature review and a research agenda. Journal of Economic Surveys, 32(5), 1384-1413. 
Zhao, T., \& Jones-Evans, D. (2017). SMEs, banks and the spatial differentiation of access to finance. Journal of Economic Geography, 17(4), 791-824. 